\title{
Teaching NeuroImage: Histopathologically Confirmed Intracranial Enchondroma/Low-Grade Chondrosarcoma and IDH1-Mutated Diffuse Glioma in Ollier Disease
}

Timothy A. Gregory, MD, and Lynne P. Taylor, MD

Neurology ${ }^{\circledR}$ 2021;97:e1747-e1748. doi:10.1212/WNL.0000000000012269

Figure MRI Brain and Hand Radiographs
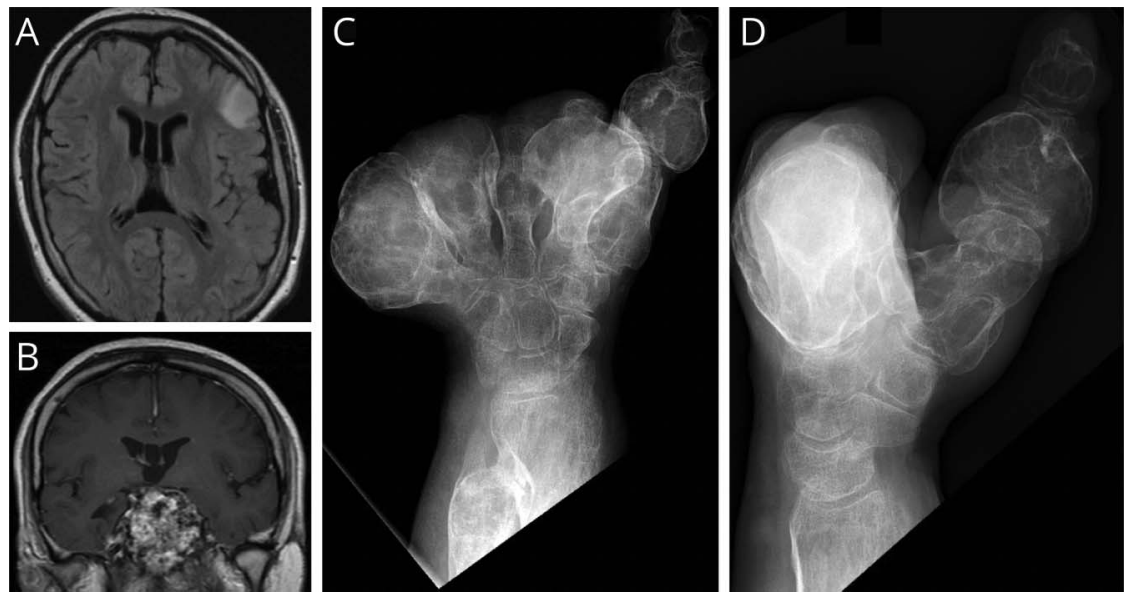

MRI brain shows IDH1 mutant grade 2 diffuse astrocytoma on fluid-attenuated inversion recovery (A) coexisting with sphenoid enchondroma vs low-grade chondrosarcoma on contrast-enhanced T1 MRI (B). Hand radiographs show enchondromatous digits that required amputation beyond metacarpophalangeal in digits 2-5 (C, D).

A 3-year-old girl presented with leg deformities diagnosed as enchondromatosis (Ollier disease), which is a rare, sporadic, skeletal disorder characterized by hamartomatous growth of cartilage cells within metaphyses of long bones. In 2008, fluid-attenuated inversion recovery signal hyperintensity in her left frontal lobe (Figure, A) and skull-base enchondroma (Figure, B) were discovered. Her enchondromatosis required amputation of digits that were heavy and unusable (Figure, C and D). In 2017, surveillance imaging revealed enlargement of the frontal tumor, leading to craniotomy for a WHO grade 2 astrocytoma. Ollier disease is associated with IDH mutations ${ }^{1}$ and patients must be monitored for sarcomatous transformation of enchondromas and extraosseous malignancies including gliomas. ${ }^{2}$

\section{Study Funding}

The authors report no targeted funding.

\section{Disclosure}

The authors report no disclosures relevant to the manuscript. Go to Neurology.org/N for full disclosures.

\author{
Correspondence \\ Dr. Gregory \\ timothyandrewgregory@ \\ gmail.com
}

\section{MORE ONLINE}

Teaching slides

links.lww.com/WNL/

B439

From the Department of Medicine, Neurology (T.A.G.), Madigan Army Medical Center, Joint Base Lewis-McCord, WA; and Seattle Cancer Care Alliance (L.P.T.), University of Washington.

Go to Neurology.org/N for full disclosures. 
Appendix Authors

\begin{tabular}{|c|c|c|}
\hline Name & Location & Contribution \\
\hline $\begin{array}{l}\text { Timothy } \\
\text { A. } \\
\text { Gregory, } \\
\text { MD }\end{array}$ & $\begin{array}{l}\text { Neurology, Department of } \\
\text { Medicine, Madigan Army } \\
\text { Medical Center, Joint Base } \\
\text { Lewis-McChord, WA }\end{array}$ & $\begin{array}{l}\text { Drafting/revision of the } \\
\text { manuscript for content, } \\
\text { including medical writing for } \\
\text { content; major role in the } \\
\text { acquisition of data; study } \\
\text { concept or design; analysis } \\
\text { or interpretation of data }\end{array}$ \\
\hline $\begin{array}{l}\text { Lynne P. } \\
\text { Taylor, } \\
\text { MD }\end{array}$ & $\begin{array}{l}\text { Seattle Cancer Care Alliance, } \\
\text { University of Washington }\end{array}$ & $\begin{array}{l}\text { Drafting/revision of the } \\
\text { manuscript for content, } \\
\text { including medical writing for } \\
\text { content; major role in the } \\
\text { acquisition of data; study } \\
\text { concept or design; analysis } \\
\text { or interpretation of data }\end{array}$ \\
\hline
\end{tabular}

\section{References}

1. Amary MF, Damato S, Halai D, et al. Ollier disease and Maffucci syndrome are caused by somatic mosaic mutations of IDH1 and IDH2. Nat Genet. 2011;43(12):1262-1265.

2. El Abiad JM, Robbins SM, Cohen B, et al. Natural history of Ollier disease and Maffucci syndrome: patient survey and review of clinical literature. Am J Med Genet A. 2020;182(5):1093-1103. 


\section{Neurology}

\section{Teaching NeuroImage: Histopathologically Confirmed Intracranial Enchondroma/Low-Grade Chondrosarcoma and IDH1-Mutated Diffuse Glioma in Ollier Disease}

Timothy A. Gregory and Lynne P. Taylor

Neurology 2021;97;e1747-e1748 Published Online before print May 26, 2021

DOI 10.1212/WNL.0000000000012269

This information is current as of May 26, 2021

\section{Updated Information \&} Services

References

Subspecialty Collections

Permissions \& Licensing

Reprints including high resolution figures, can be found at: http://n.neurology.org/content/97/17/e1747.full

This article cites 2 articles, 0 of which you can access for free at: http://n.neurology.org/content/97/17/e1747.full\#ref-list-1

This article, along with others on similar topics, appears in the following collection(s):

All Oncology

http://n.neurology.org/cgi/collection/all_oncology

Burden of disease

http://n.neurology.org/cgi/collection/burden_of_disease

MRI

http://n.neurology.org/cgi/collection/mri

Primary brain tumor

http://n.neurology.org/cgi/collection/primary_brain_tumor

Information about reproducing this article in parts (figures,tables) or in its entirety can be found online at:

http://www.neurology.org/about/about_the_journal\#permissions

Information about ordering reprints can be found online:

http://n.neurology.org/subscribers/advertise

Neurology ${ }^{\circledR}$ is the official journal of the American Academy of Neurology. Published continuously since 1951, it is now a weekly with 48 issues per year. Copyright @ 2021 American Academy of Neurology. All rights reserved. Print ISSN: 0028-3878. Online ISSN: 1526-632X.

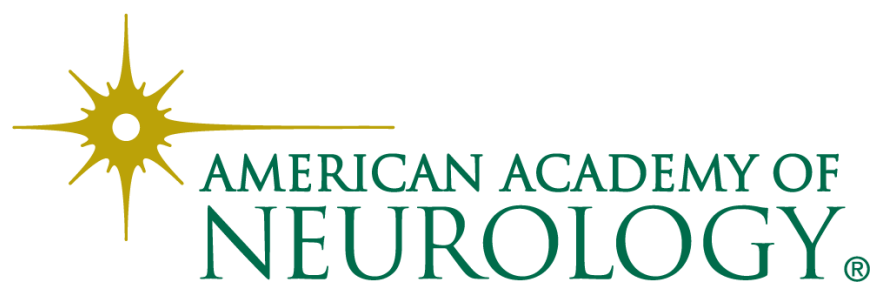

